\title{
Old homes and new homelands: imagining the nation and remembering expulsion in the wake of the Mali Federation's collapse
}

\author{
Marie Rodet and Brandon County
}

\section{Introduction}

The Mali Federation collapsed on the night of 19-20 August 1960. It was the tragic end of an ambitious project to preserve ties between French West Africa's eight territories as nationalist politicians renegotiated their relationship to France and the French empire. The idea of African federalism was not new on the continent but gained its momentum in the 1950s and 1960s against the backdrop of expanding pan-Africanist ideas and decolonization, which led to the creation of several federations such as the Ethiopia-Eritrea Federation (1952) and the East African Community (1967). Most of these federal experiences were deemed to fail, though mostly due to increasing competition over political leadership and differing socio-political views, in a context of heightened tensions between socio-cultural diversity and emerging territorial and national identity. In the case of the constitution of the Mali Federation, whose main initial political goal was to preserve the unity of the late French West African Federation, France and Côte d'Ivoire clearly opposed the project in defence of their political and economic interests and ultimately succeeded in preventing Upper Volta and Dahomey from joining in 1958 (Kurtz 1970).

In its final phase, the Mali Federation joined only Senegal and the Sudanese Republic in a union that lasted only nineteen months - and only two months of formal independence. In the final two months, preparations for the Mali Federation's presidential election exacerbated social and political tensions as Léopold Sédar Senghor and Modibo Keita rallied supporters in their respective constituent republics. The campaign for the federal presidency represented two different ideas of nationalism and decolonization: Senghor, president of the Mali federal assembly, wanted to maintain ties with France, and believed in distinct and discrete nationalities; Keita's Union Soudanaise-RDA (Rassemblement Démocratique Africain, hereafter US-RDA) favoured a definitive break with the colonial past, closer relations with the Soviet bloc, and an incorporative idea of the nation that would, over time, unify postcolonial categories of belonging into an inclusive and expanding panAfrican federalism.

\footnotetext{
Marie Rodet is a senior lecturer in the History of Africa at SOAS, University of London. Her research interests lie in the fields of modern migration history, gender studies and the history of slavery in Francophone West Africa. Email: mr28@soas.ac.uk

Brandon County teaches history at Lorain County Community College. He has published a number of articles on the postcolonial history of Mali. Email: bcounty@lorainccc.edu
}

(C) International African Institute 2018 
A week before the election, Keita, the federal government's provisional head, accused Senegalese leaders of plotting with Paris to dissolve the Federation. Senghor and Mamadou Dia, vice-president of the Federation, in return mobilized Senegalese troops to secure against fears of a Sudanese coup. In a suburban Dakar station thirty-six hours later, 130 people under military guard - all high-ranking Sudanese officials and their families were forced aboard an express train bound for Bamako. The passengers disembarked at Kidira, the riverside town that marked both the geographic centre of the Dakar-Niger railway and the border between the Federation's two constituent republics. Now, it was the end of the Senegalese line. Crossing the railway bridge on foot, Modibo Keita entered the Sudanese Republic to a hero's welcome. He climbed aboard a Sudanese train and continued eastward to Bamako. At every station, crowds turned out to cheer Keita and hear his denunciation of the federal collapse, French neocolonialist designs, and the treachery of the Senegalese politicians who had struck a bargain to trade African unity for national sovereignty. Within a month, politicians in Senegal and the renamed Republic of Mali, rushing to salvage political legitimacy from the federal wreckage, had proclaimed separate independences on each side of their shared border. ${ }^{1}$

For the cheminots (railwaymen) of the Dakar-Niger railway, their families and, more generally, the Sudanese living in Senegal, the Federation's collapse brought different problems. Under French rule, inter-territorial labour unions and migration had shaped politics and social ties that spanned the colonial borders. As in other colonial territories on the continent, those railwaymen forged alliances and came to the forefront of socio-political movements against colonial rule and its discriminatory policies (Cooper 1996; Grillo 1973). Yet, with the tense independence that split 1,288 kilometres of railway, people in station towns were forced to re-evaluate their relationship with their places of residence. For those populations originally from French Sudan who had been living in Senegal for decades, and sometimes even for several generations, the collapse forced the difficult choice of either staying in a country whose political leaders had overtly expressed great hostility towards their now ascribed 'homeland' or returning to a country that they or their ancestors had left under very different political and social circumstances. In the following months, patriotic appeals and administrative pressures persuaded thousands of cheminots, their families, and other Sudanese populations living in Senegal to cross the Falémé River and return to their 'homeland' over the now international border. In Malian Kayes, Senegalese Thiès and the other railway towns between Dakar and Bamako, generations of trade, travel, migration and labour activism had sustained ties and shaped expectations that differed from national priorities set in new national capitals (Jones 2002; Rodet and County forthcoming). Indeed, populations along the railway had developed enduring intergenerational and translocal links between Mali and Senegal, with people regularly travelling back and forth between regions along the railway (Rodet 2008). They shaped translocal communities through specific

\footnotetext{
${ }^{1}$ This narrative draws from République du Sénégal (1960), Foltz (1965), Kurtz (1970), Campmas (1978), Ndiaye (1980), Diarrah (1986), Cissoko (2005), Joly (2014) and Cooper (2015).
} 
remembering of 'home' and 'homeland' (indeed, in 'remembering', one can find 'member'; see Rodet and Reinprecht 2013). ${ }^{2}$

Stung by Senegalese leaders' actions, the Sudanese Republic closed the border to all trade with its former partner. ${ }^{3}$ The Dakar-Niger railway and the people who lived by it suffered the most immediate effects of this decision. Senegalese officials in Bakel, on the border with Mali, had complained that Malian customs agents had confiscated over 750,000 CFA francs from Senegalese nationals crossing from Mali in September and October 1960. ${ }^{4}$ In turn, these officials began to confiscate cash held by migrant workers returning to Mali in early $1961 . .^{5}$ Besides, with international freight traffic blocked, Senegalese railway operations changed dramatically. Kidira, the station town that had marked the midpoint of the federal railway, was transformed into a distant outpost in independent Senegal's eastern borderlands. The Senegalese railway's centre of gravity shifted to the urban centres of the coast and the trading stations in the peanut basin. With service reduced, the Senegalese railway authorities began to reduce the number of workers employed. Approximately one-quarter of the more than 5,000 cheminots working in Senegal had been 'Nationals of the Sudanese Republic' under federal law. ${ }^{6}$ Most of the railway's administrative staff in Thiès hailed from the Sudanese Republic. ${ }^{7}$ Far fewer Senegalese cheminots worked in the smaller railway centres on the Sudanese side of the border. ${ }^{8}$ Any exchange of nationals would be lopsided.

The political implications of the Federation's collapse have been widely analysed by political scientists and historians alike, but the social dimensions and the lived experiences of those events by the concerned populations - cheminots and others - have been barely touched upon. This article explores these often unheard voices of the decolonization process in West Africa. In particular, it attempts to examine how Sudanese populations who were settled in Senegal at the time of the Federation's collapse navigated the national identity that was newly ascribed to them by the Senegalese and Malian authorities and the extent to which their experiences and memories of 'home' and 'homeland' permeated the way in which they adapted to the new political situation.

Here, memories and migration were certainly central social and political challenges of decolonization: migrants' experiences and practices sometimes conflicted with new national memories in the making, highlighting the complexities of the processes of building a national identity in the wake of independence. Thus, examining complex histories and memories of 'home' and 'homeland' along the Dakar-Niger railway, this article sheds light on multi-layered and

\footnotetext{
${ }^{2}$ On 'remembering', 'dismembering' and 're-membering', see Ngũgĩ wa Thiong'o (2009).

${ }^{3}$ 'Écoute Radio-Bamako mercredi 31 Août 1960', p. 3, Fonds Sénégal independent (FSI) 149, Archives nationales du Sénégal (ANS).

${ }^{4}$ 'Cdt Bakel to Min Interieur Senegal', \#4/CF-CB, 2 February 1961, FSI 201, ANS.

${ }^{5}$ 'Entretien avec les autorités Sénégalaises à TAMBA le 28-2-61', 28 February 1961, Fonds du Bureau politique national (FBPN) 88/300, Archives nationales du Mali (ANM).

${ }^{6}$ RCFS, 'Compte-rendu de gestion', 20 August-31 December 1960, p. 7, Fonds du Gouvernement général d'Afrique occidentale française (GGAOF) 2G 60/6, ANS.

7Renseignements (confidential)', 1 September 1960, 5D 14, Service régional des Archives du Sénégal à Dakar (SRAS-Dakar).

${ }^{8}$ RCFS, 'Compte-rendu de gestion', 20 August-31 December 1960, p. 7, GGAOF 2G 60/6, ANS.
} 
sometimes competing processes of both national and diasporic identity building at the time of the decolonization process in West Africa. The article ultimately attempts to examine how perceptions of the past, in confrontation with the political and social realities of the time, affected the incorporation of 'migrants' in independent Senegal and Mali.

\section{Disputed memories of belonging: territory, nationality and affiliation in the Mali Federation}

In order to prevent the balkanization of French West Africa, the Sudanese Republic merged on 4 April 1959 with Senegal to form the Mali Federation, which became entirely self-governing when it gained independence from France on 20 June 1960. The idea of this formation mainly relied on both a panAfricanist ideal and the memories of long-standing economic, social and cultural connections dating back to the West African precolonial empires. Over generations, and in a much more accelerated manner since the construction of the Dakar-Niger railway under French colonial rule at the beginning of the twentieth century, numerous families had built translocal lives sustained by continuous flows of people, goods and experiences back and forth and intermarriages over several generations from the Sudanese hinterland to the Senegalese coast (David 1980; Manchuelle 1997; Rodet 2009; 2015). Many people living and working in Senegal in the 1950s located their family history in French Sudan and thought of it as 'home', even if they had spent little or no time there.

Under the federal Malian structure, Sudanese politicians and technocrats had moved into the administrative offices of the former French West Africa and the stately villas of the former French administrators. Senegalese officials and citizens chafed at seeing Sudanese in offices that had been disproportionately staffed by Senegalese clerks during the period of French rule. An anonymous Senegalese bureaucrat complained that 'you had to speak Bambara to get anything done in the Administrative Building', so great was the Sudanese presence (Foltz 1965: 148). Acutely aware of the Federation's demographic imbalance, many Senegalese worried that Sudanese interests would dominate the new state, just as the growing cadre of Sudanese bureaucrats seemed to dominate Dakar (Ndiaye 1980: 31-2). Speaking in Wolof just days before the Federation's collapse, Mamadou Dia made an even more unlikely claim. 'Our country was colonized by France. Today we no longer suffer this arrangement. We have become free and independent. It is not to allow another country, and above all a territory so similar to our own, to come and colonize us in turn' (quoted in Zuccarelli 1988: 82).

The same day Modibo Keita's train left Dakar, Sudanese cheminots in Thiès, 'visibly sad' at the news, wondered aloud about their fate in Senegal. ${ }^{9}$ The physical rails quickly became 'Senegalese' when the railway was nationalized after the Federation split, but for people living and working along the rails, the question of citizenship was more hotly contested. Dialimady Koité, secretary-general of

\footnotetext{
9'Compte rendu de renseignements fournis par le groupe de Thiès sur la situation politique', \#3/S, 21 August 1960, 5D 14, SRAS-Dakar.
} 
Mali's railway workers' union, condemned the events in Dakar and proclaimed the union's indefatigable support for 'the Malian cheminots living in Senegal'. ${ }^{10}$

Officials in Bamako recognized that the cash-poor country would require considerable human effort to meet their socialist goals. They appealed to expatriate citizens of the former Sudanese Republic to 'return' and build the new Mali (Gary-Tounkara 2008: 200-2). ${ }^{11}$ The call was addressed particularly to cheminots working in Senegal, many of whom had graduated from colonial French Sudan's few technical schools. ${ }^{12}$ While Keita, Koité and other political leaders pleaded with skilled workers to join Mali's new national railway, Senegal had a different problem. Graduates of Bamako's Terrasson de Fougères technical school dominated the railway's highest ranks. Thus, Senegalese cheminots and trade unionists often attempted to convince their Sudanese colleagues and friends to stay despite the collapse, claiming that the collapse was purely political, and they ultimately remained united as cheminots. ${ }^{13}$

In the twilight of empire, nationalist politicians and new states in West Africa assumed that family histories rooted in colonial and precolonial territories and polities would extend to postcolonial citizenship (Malkki 1992; County and Skinner 2008; Mann 2015). With the September 1960 'socialist option' of the Republic of Mali, Modibo Keita announced that the new state included people far beyond its borders. In a radio broadcast, he named several prominent Federation loyalists from Senegal. The new republic included them 'and all the other Senegalese who have remained faithful to their vows and their commitment to the Federal government'. ${ }^{14}$

The question of nationality before the Federation's collapse had primarily been a Senegalese question. Long the seat of the French West Africa government, Dakar maintained its political primacy in 1959 when it was named the Mali Federation's capital. Frederick Cooper claims that the politicians and intellectuals in charge of Senegal in the late 1950s argued for a distinction between a unified citizenship for all Africans living in the French Union (and later French Community) and a set of nationalities whose membership would be determined by territorial governments (Cooper 2015). Yet Modibo Keita, on the Sudanese side, had been hostile to a unified citizenship and more generally opposed to further common institutions with France within the framework of the French Community. And despite the Senegalese claims for a unified citizenship, a practical distinction between Sudanese and Senegalese had a long history in Senegal, which relied on the memories of the two distinct cultural, economic and social spaces of the colonial era instead of the historical continuum claimed by political leaders at the time of the constitution of the Federation.

\footnotetext{
${ }^{10}$ Dialimady Koité, speech at Congrès des Cheminots du Mali, 25-26 September 1960, BK 26, ORTM Archives sonores.

${ }^{11}$ Interview by Brandon County with Bibata Maïga, 25 December 2008, Markala (Diamarabougou), Mali.

${ }^{12}$ Interview by Isaac 'Chaka' N'Diaye with Mamadou Sidibé, 19 January 2008, Kita, Mali.

${ }^{13}$ Interviews by Marie Rodet with Mahamadou Sacko, 4 February 2007, Bamako (railway station), Mali; Cheik Doumbia, 4 February 2007, Bamako (railway station), Mali; Cheick Sidiya Diombana, 5 February 2007, Bamako (Badalabougou), Mali; Cheikh Oumar Tabouret, 16 April 2008, Bamako (Lafiabougou), Mali.

14'République du Mali-Soudan', 24 September 1960, 5D 14, SRAS-Dakar.
} 
The term 'Bambara' in particular had a long history of praise and stigmatization in Senegalese (colonial) records, where they represented the 'other', and very often the slaves. ${ }^{15}$ The cheminots and their families heading from French Sudan and living in Senegal on the eve of the Federation's collapse further experienced this distinction: while they were often called 'Sudanese' or 'Bambara' by the local Senegalese populations, they also attempted in some cases to defend their specificity by priding themselves on keeping Bamanankan as the main language spoken at home and on maintaining social ties with their 'homeland' through the steady flows of information, goods and people along the Dakar-Niger railway (Rodet 2015). Mahmadou Sacko, whose father worked as a construction supervisor for the Dakar-Niger railway in the early twentieth century, explained how he and his siblings were forbidden by their parents from speaking Wolof at home in Thiès. ${ }^{16}$

Distinction was also reinforced by the railway reorganization and the devolution of its competencies to the former administrative regions, as well as 'Africanization' measures that replaced metropolitan French employees with Africans in the post-war processes of decolonization. The commission charged with dividing the federal colonial railway authority issued a decision that localized the employment of cheminots, transferring employment status and pension responsibility from the former colonial railway divisions (régions) to the newly autonomous public companies (régies). It created the category of 'dépaysé' (relocated), which was applied to African workers from outside the colony who received financial compensation for working away from home (Tixier 1965: 931-2). This in turn led to a series of personnel moves that these new authorities designed in order to cut costs by reducing the number of workers from outside the territory of each new régie (ibid.: 923-4). Thus, the 4 February 1960 order that eliminated the category of 'dépaysé' was particularly important in the Mali Federation. Levelling pay provided a disincentive for cheminots to remain in jobs outside their home territory, but it also equalized payment for all Malians no matter which constituent republic they called home. Yet, despite the official abolition of relocation bonuses in February, the Dakar-Niger railway still calculated expatriate worker salaries at a higher rate. The expatriate category initially applied to French cheminots working in the colonies, but Senegal's declaration of independence from the Mali Federation transformed de facto Sudanese cheminots from nationals to expatriates. Worried about the increased labour costs and the possibility of layoffs should the railway administration decide to keep some or all of its top-level Sudanese employees on the expatriate pay grade, Senegalese cheminots protested against any such unequal pay scale. ${ }^{17}$ Rumour spread that the Senegalese government would not pay Thiès's sizeable contingent of Sudanese at all. ${ }^{18}$

\footnotetext{
${ }^{15}$ On the genealogy of the term, see Bazin (1985).

${ }^{16}$ Interview by Marie Rodet with Mahamadou Sacko, 4 February 2007, Bamako (railway station), Mali.

${ }^{17}$ 'Comités de Vigilance des Cheminots', 19 September 1960, 5D 14, SRAS-Dakar.

${ }^{18}$ Interview by Brandon County with Maciré Coulibaly, 22 July 2007, Thiès (Diamaguène), Senegal.
} 
Immediately after the Federation's collapse, more than four-fifths of the cheminots working in Senegal were Sudanese, and although Senegal's national railway could certainly not maintain this entire workforce, if all of them left the country and the railway at the same time, the railway risked being paralyzed. ${ }^{19}$ At the beginning of September 1960, at a meeting of Sudanese Terrasson graduates in Rufisque, a teacher working in Dakar said that if Sudan's cheminots and public works employees left Senegal, Sudan could reconquer the rebellious republic and reunite the Federation, ${ }^{20}$ a statement that echoed to some extent some of the concerns addressed by Dia before the collapse.

In its truncated 1960 annual report, Senegal's newly created national railway authority stated that it could not maintain the workforce it had inherited and, in October 1960, it decided that members of 'the group of Sudanese serving in Senegal' would 'return to their country of origin'. ${ }^{21}$ In the second week of October, 400 cheminots and their families boarded trains in Thiès for an overnight voyage that would end at the border at noon. ${ }^{22}$ Railway officials on both sides of the border were unsure if they could send the Senegalese train into Malian territory, so the passengers disembarked at Kidira, trudged across the railway bridge to Diboly, and boarded trains sent by the Republic of Mali's newly organized national railway. By November, over 1,000 cheminots - and several thousand relatives and dependants - had crossed the Falémé bridge. ${ }^{23}$ Other state employees with ties to Sudan also left Senegal in response to official decisions, social pressures and political appeals (Traoré 2005: 80-2). ${ }^{24}$ Reluctant repatriates and anticipatory nationalists alike bade farewell to their jobs, their friends and their families in Senegal, loaded their possessions onto eastbound trains, and 'returned' to the Republic of Mali for the very first time.

The Federation's collapse certainly became a founding national moment for the newly declared Republic of Mali, which henceforth experienced a particularly heightened nationalist climate (Campmas 1978: 199; Rillon 2013: 92). When the Republic of Mali and families in Mali called on their children abroad to 'return', this call garnered an overwhelming response. People who had spent only months in Senegal headed east alongside people who had been born there. Cheik Doumbia, who was born in Kaolack of Sudanese parents and had been

\footnotetext{
${ }^{19}$ 'Renseignements', 1 September 1960, 5D 14, SRAS-Dakar.

${ }^{20}$ 'Renseignements', 8 September 1960, 5D 14, SRAS-Dakar.

${ }^{21}$ RCFS, 'Compte-rendu de gestion', 20 August-31 December 1960, p. 7, GGAOF 2G 60/6, ANS.

${ }^{22}$ 'Chef Service Exploitation [Thiès] to Chefs Service Exploitation [Bamako and Dakar]', \#4-T, 5 October 1960, FBPN 88/300, ANM.

${ }^{23}$ Government officials used a figure of 1,046 and the cheminots' union cited 1,048. 'Min Fonction Publique Travail Affaires Sociales', PV, 9 October 1961, FBPN 181/622, ANM; '1 Congrès ordinaires [sic] du Syndicat des Cheminots du Mali: rapport moral d'activité', p. 3, 18-20 March 1962, 1W 21 dossier 'Police spéciale du Chemin de fer 1961-1963', AGRK. Cheick Doumbia mentioned 1,700 repatriates in the country in November 1961, but his categories might be more expansive, including temporary and contract workers. Interview by Brandon County with Cheick Doumbia, Bamako (railway station), Mali, 13 March 2009. The figure of 2,700 cited by Daouda Samaké is probably mistranscribed (Samaké 1998: 24).

${ }^{24}$ See also 'Liste nominative des gradés et gardes républicains originaires du Soudan remis à la disposition du gouvernement de leur pays à compter du ler novembre 1960', FSI 11D 1/1393, ANS.
} 
working for the railway since 1951, had never thought of resettling in Mali, but after the Federation collapsed, his father, a stationmaster in Kayes, sent a telegram: 'come if you have received decision'. The younger Doumbia had no choice but to obey his father's call. ${ }^{25}$ Government bureaucrats, cheminots, artisans and students all heeded similar calls. Young mothers boarded the eastbound trains with newborn babies in their arms. ${ }^{26}$ After a difficult trip, a festive and patriotic reception met them at the border. The US-RDA leadership in Kayes mobilized party activists, musicians, dancers and cooks to transform the experience of expulsion into a happy homecoming. 'Fasobaara, anw ka fasobaara ke,' they sang in Bamanankan, exhorting each other to 'work to build the nation' ${ }^{27}$ Every day for nearly three weeks, 300 to 400 volunteers set out from Kayes in special trains. Members of the US-RDA women's association cooked meals for the repatriates to eat after they arrived on Malian soil and social workers provided first aid for adults and children. ${ }^{28}$ Similar scenes were repeated in each station of the railway from Kayes to Bamako. ${ }^{29}$ The repatriated drifted to the homes of friends and relatives, or slept in converted public buildings and used Kayes as a staging area as they contacted relatives further down the line to arrange for more permanent accommodation. A retired cheminot in Mahina donated 100 kilograms of rice and slaughtered a bull to help feed the refoulés lodged in and around the station. He also took up a collection to meet the new arrivals' needs and received 4,500 CFA francs, or approximately one month's salary for a new worker. ${ }^{30}$ In the neighbouring administrative centre of Bafoulabé, residents denounced Senghor and Dia and demanded that all ties with Senegal be cut. Some of the town's older residents, recalling their experiences as migrant labourers in Senegal, were not surprised by the events in Dakar. Acerbically they assured young Malians that 'these acts of treachery are not new'. ${ }^{31}$

In Bamako, officials made creative use of the resources available to help integrate repatriated workers. West of the city centre, 2,000 families of repatriates and urban migrants moved into waterlogged but free plots of land (Samaké 1998: 35). ${ }^{32}$ On the national level, the government deducted a small portion of the wages earned by the country's formal sector workers and used the money to

\footnotetext{
${ }^{25}$ Interview by Marie Rodet with Cheikh Doumbia, 17 January 2008, Bamako (railway station), Mali.

${ }^{26}$ Interview by Brandon County with Bibata Maïga, 25 December 2008, Markala (Diamarabougou), Mali.

${ }^{27}$ Interview by Brandon County with Makanba 'Martin' Kanouté, 5 August 2009, Kayes (Khasso), Mali.

${ }^{28}$ Cercle Kayes, monthly report, September-October 1960, 'Revue mensuelle des évènements (RME) 10', Archives du Ministère des affaires territoriales et des collectivités locales du Mali (MATCL); Arrondissement Oualia, monthly report, November 1960, RME 9, MATCL; Cercle Kita, monthly report, November 1960, RME 9, MATCL; Cercle Kita, monthly report, October 1960, RME 10, MATCL; Cercle Kita, monthly report, November 1960, RME 9, MATCL.

${ }^{29}$ Cercle Bafoulabé, monthly report, November 1960, RME 9, MATCL.

${ }^{30}$ 'Félicitations au nom des cheminots rapatriés de Sénégal en résidant au Cercle de Bafoulabé', late 1960 or early 1961, FBPN 79/267, ANM.

${ }^{31}$ Cercle Bafoulabé, monthly report, September 1960, RME 9, MATCL.

${ }^{32}$ The largest of these neighbourhoods, Lafiabougou ('serenity town' in Bamanankan) was allocated in 1961 as a refuge for Malians expelled from Senegal and Congo-Léopoldville. Interview by Marie Rodet with Birama Traoré, 7 June 2008, Bamako (Lafiabougou), Mali. See also Traoré
} 
establish a solidarity fund that paid repatriated cheminots half-salaries for twelve months, allowing them to meet their families' basic financial needs while officials worked to place them in new jobs (Traore 2005: 82). ${ }^{33}$ Some left to work on the railways in neighbouring Guinea and Côte d'Ivoire. ${ }^{34} \mathrm{~A}$ few others went further afield to technical training programmes in Yugoslavia. ${ }^{35}$

The plight of the repatriated cheminots had become rhetorically tied to the country and, more broadly, to the continuing political struggle against imperial domination. ${ }^{36}$ On Radio Mali, announcers read a letter allegedly sent by sympathizers in Dakar who celebrated the new republic as a victory over French neocolonialism. They were careful to highlight that 'the Malians expelled from SENEGAL leave stronger because of their ordeal ... because those who have the sympathy of their people and of another people are twice as strong'. ${ }^{37}$ The US-RDA leadership continued to thank party members in Kayes for their support of 'our brothers expelled from Senegal', one of the locality's many sacrifices 'to safeguard the dignity and the liberty of the whole Nation'. ${ }^{38}$ Maintaining attention to the railway, Senegalese dissidents based in Bamako broadcast their disgust over 'the anguish in which the [Senegalese] cheminots have lived ... [S]ince the manufactured collapse of the Mali Federation, the Senegalese railway reports more than a billion [CFA francs] in deficit despite the shameful repatriation of Malian cheminots.' 39

Yet, as we shall see, some of the repatriated cheminots and the Sudanese living in Senegal who returned to Mali experienced a long and precarious journey in the process of resettlement, which disrupted their initial memories of 'home' and 'homeland' and their sense of belonging.

\section{Failing memories? The practicalities of belonging}

Most people recognized the symbolism of the early days of the Malian Republic, such as when the population of Bafoulabé 'congratulate[d] the party faithful of Kayes for how they handled the situation of the cheminots', and, because the trains' late arrival prevented them from offering such a spectacular welcome,

(2005: 82). Claude Meillassoux refers to the neighbourhood as 'Lafadié', possibly from lafiya je or 'sharing serenity' (Meillassoux 1968: 14).

${ }^{33}$ Interviews by Marie Rodet with Cheik Doumbia, 4 February 2007, Bamako (railway station), Mali; Cheick Sidiya Diombana, 5 February 2007, Bamako (Badalabougou), Mali.

${ }^{34}$ Police Spéciale Kayes, 'Renseignements: A/s Réunion syndicale des Cheminots', \#02/PSK-C, 23 January 1962, 1W21, Archives du Gouvernorat de la Région de Kayes (AGRK); 'Mémoire présenté par le Bureau de l'Union Nationale des Travailleurs du Mali sur les suggestions du Ministre des Finances concernant la proposition du Budget d'État (exercice 1967-1968)', FBPN 105/406, ANM.

${ }^{35}$ 'Secretariat Gen Min Fonction Public', PV, 9 October 1961, FBPN 181/622, ANM.

${ }^{36}$ Police Spécial Kayes, 'Renseignements: Réunions syndicales des cheminots', 28 August 1961, 1W21, AGRK.

37 'Radio-Mali: émission de 12h45', 24 October 1960, 5D 14, SRAS-Dakar.

38،BPN to Sec Gen BPL Kayes', \#93, 10 October 1962, FBPN 239/857, ANM.

${ }^{39}$ 'Appel du PAI (à l'occasion du 2ème anniversaire de l'Indépendance du SENEGAL) lancé sur les ondes de Radio Mali le 4 avril 1962 à 12 heures 45', DIMI 10T 735, Service historique de la défense, France (SHD). 
they decided to redeem themselves by contributing more to the solidarity fund. ${ }^{40}$ Government officials fretted over the slow pace of job creation and job placement for repatriated cheminots. The solidarity fund was meant to pay out after one year, a fact that the head of the railway nervously raised in a meeting of Bamako's regional officials in September 1961. ${ }^{41}$ When the fund did end, it became both a pressing concern for those cheminots still without jobs and a test of the government's ability to give economic shape to its political rhetoric. Auxiliary workers, the lowest rank of permanent employees, were particularly worried. Police reports in Kayes noted that their situation 'remains as confused as ever, and this has caused them to worry'. Union officials promised new jobs in state industrial ventures, but cheminots recognized that 'the positions taken up by the Government have not always brought concrete results. A new worksite with 500 jobs cannot be achieved in the short term. Workers see the reality of this proposition and they remain pessimistic and impatient to hear the government's official decision. ${ }^{42}$

The arduous wait for news and jobs drove many cheminots to reappraise the possibilities offered by the new state. Those who secured work on the railway often traded prestige for employment. Mechanics took up partial employment as manual labourers, with hours slashed in order to offer part-time jobs to the remaining unemployed cheminots. ${ }^{43}$ In this context, the letter from a woman on behalf of her repatriate brother takes on extra significance. She pleaded with the governor of Kayes to find or create even a part-time job 'to save us from disgrace'. And, while the letter described her immediate family's dire straits, it also evoked a national concern. ${ }^{44}$ In 1961, one man wrote to the regional governor in Kayes and alluded to the connection between repatriated workers and the state's duty to address the problems created by repatriation. Emphasizing his patriotic choice to leave Senegal, he introduced himself as 'a mechanic by profession' who had not worked in his field of expertise since 1956.

I will gladly accept any task that is assigned to me in order to meet the needs of my family ... I used to live in Senegal, [and] at the collapse of the Mali Federation, I came to reinforce the ranks of those who build the Malian Nation, since all Malians aware of their duties had to return to Mali after all that the Senegalese had done. ${ }^{45}$

Two months later, at a union meeting, a certain Diombana ${ }^{46}$ publicly criticized the government's decision to encourage expatriates to return, since their subsequent unemployment had exposed the new republic's economic fragility. He continued, saying that: 'The work of the Government, as gigantic as it may be, will be in vain if one single repatriated worker remains unemployed, for it was shouted from the

\footnotetext{
${ }^{40}$ Cercle Bafoulabé, monthly report, October 1960, RME 10, MATCL.

41 'PV de la première conférence régional trimestrielle de la Région de Bamako', 29 September 1961, 1W13, AGRK.

${ }^{42}$ Police Spéciale Kayes, Report, November 1961, 1W21, AGRK.

${ }^{43}$ Interview by Isaac 'Chaka' N'Diaye with Mamadou Sidibé, 19 January 2008, Kita, Mali.

44'Sow Aminata to "Cher Ly" [GRK]', 17 July 1961, 1W8, AGRK.

45، Coulibaly Birima to GRK', 11 December 1961, 1W8, AGRK.

${ }^{46}$ Although identified in the report as 'Moussa Diombana', the speaker is almost certainly Cheick Sidiya Diombana.
} 
rooftops [in Senegal] that Mali will be incapable of accommodating all its repatriates. ${ }^{47}$ Diombana even claimed years later that he personally had regretted coming back to Mali: had he known what it would be like, he would have stayed in Senegal. ${ }^{48}$ Some graduates of École Terrasson also wrote to complain that they still had not found work years after the Federation's collapse. ${ }^{49}$ 'Modibo was the first one expelled from Senegal,' cheminots often said in the early 1960s as a wry comment on how they felt betrayed by the new government. ${ }^{50}$ Some cheminots' wives did not hesitate to castigate the Malian railway authorities about the conditions of their repatriation: numerous pieces of luggage had gone missing during the transfer from Kidira to Diboli. ${ }^{51}$

Some of the repatriated soon became the objects of political suspicion and appeared as the new 'enemies within' since they did not intend to bend to the party's discipline. ${ }^{52}$ Diombana spent some time in prison for insisting that, rather than force demoralized cheminots to squander their mechanical expertise and adopt agricultural labour, the government should have supported them so that the new country could profit from their skills. ${ }^{53}$ Indeed, shortly after the welcome in Kayes, government representatives had come to railway towns and urged cheminots to take up farming jobs. Officials, including the mayor of Kayes (a cheminot union leader in the 1950s) and the national labour union coalition, criticized cheminots for refusing to farm, raise livestock and gather wood. One self-styled patriot in Kayes offered the national government his unsolicited advice, suggesting that the state provision the towns and villages along the railway so that 'all the native Malians now living in Senegal' could return to Mali and 'labour together to build the nation'. ${ }^{54}$ Some cheminots did transfer their employment to work as local administrative agents, teachers or technical experts elsewhere in the country. ${ }^{55}$ This seemed to be more out of necessity than choice, and government officials complained bitterly that cheminots were not interested in open posts outside the railway. ${ }^{56}$ The government expected cheminots

\footnotetext{
${ }^{47}$ Police Spéciale Bamako, 'Renseignements', \#16/C/PS-B, 1 February 1962, FBPN 64/191, ANM.

${ }^{48}$ Interview by Marie Rodet with Cheick Sidiya Diombana, 5 February 2007, Bamako (Badalabougou), Mali.

${ }^{49}$ 'Sountougoumba Kéita to Sec Gen US-RDA s/c BPL Kita', \#13 BPK, Kita, 1 October 1964, FBPN 240/861, ANM; interview by Brandon County with Cheick Doumbia, 13 March 2009, Bamako (railway station), Mali.

${ }^{50}$ Moussa Diabaté's speech in Police Spéciale Bamako, 'Renseignements', \#16/C/PS-B, 1 February 1962, FBPN 64/191, ANM; interview by Brandon County with Assa Dabo, 29 December 2008, Markala (Kirango), Mali.

${ }^{51}$ Interview by Marie Rodet with Mrs Tabouret, 16 April 2008, Bamako (Lafiabougou), Mali.

${ }^{52}$ Interviews by Marie Rodet with Cheikh Oumar Tabouret, 16 April 2008, Bamako (Lafiabougou), Mali; Birama Traoré, 7 June 2008, Bamako (Lafiabougou), Mali; Cheick Doumbia, 4 February 2007, Bamako (railway station), Mali.

${ }^{53}$ Interview by James Jones with Cheick Sidiya Diombana, 16 April 1992, Bamako.

54،Un Malien qui songe à la grandeur de la Nation' to 'Messieurs Les Présidents et Membres du Conseil du Ministre de Gouverneur [sic] de la République du Mali', 29 March 1961, FBPN 239/ 857, ANM.

${ }^{55}$ Interviews by Isaac 'Chaka' N'Diaye with Mamadou Keita, 23 November 2007, Negala, Mali; Mamourou Keita, 9 September 2007, Toukoto, Mali; interview by Brandon County with Cheick Doumbia, 13 March 2009, Bamako (railway station), Mali.

56، Min Intérieur to Sec Gen BPN', \#697/MII-CAB, 16 June 1961, FBPN 112/428, ANM.
} 
to do whatever work was asked of them - most commonly agricultural labour - in the same way as they requested the youth to 'return to the land' to build the new nation (Gary-Tounkara 2008; Rodet and County forthcoming). ${ }^{57}$

Such a predicament demanded sacrifices. In a meeting in late November 1962, Dialimady Koite tried to encourage the members of his union to identify with the nation, asking them to 'work more than ever because it is necessary to build the nation'. ${ }^{58}$ At the same meeting, Sibiri Kanouté, a delegate from Kayes, accepted the importance of nation building while he lambasted the government's attempts to draw the cheminots closer to the state:

At the railway, you don't dare speak because you risk being labelled 'anti-nationalist' ... All the cheminots here have things to say. Who among you has nothing to say? ... But you don't dare. We struggled to chase away the European colonialists because they did not support the interests of the workers and the country. But those who are at the head of the railway now did not earn their place there ... We cheminots, we are determined to work in the country's best interests, but this burden must not be carried by the workers alone, it must be carried by everyone. ${ }^{59}$

Everyone agreed that something had to be done to assist the repatriates who remained unemployed, but cheminots in Kayes had a more pointed critique, arguing that the fallout from the Federation's collapse was part of a national problem and not simply a problem for the railway. ${ }^{60}$

While publicly proclaiming the repatriated cheminots' civic virtue, US-RDA leaders recognized that they often returned from Senegal carrying a different set of political values. Reports from Kita noted 'with satisfaction' that cheminots arriving from Senegal had made public declarations in favour of the new state and had conducted themselves well since their arrival. ${ }^{61}$ In other towns, they challenged the established political leadership, for example when a group of repatriates in Bafoulabé accused the area's National Assembly deputy of cronyism and corruption. ${ }^{62}$ The spark for this was that the deputy, Hamady Diallo, had said that all the refoulés could not possibly stay in Mahina.

Within the railway workers' union, repatriated cheminots formed an important interest group that coalesced into an irritated voting bloc as hundreds of them remained unemployed more than a year after arriving with the expectation of working for Mali's national railway. A government report on the railway warned that the repatriates 'recognize neither the union Leadership nor the Railway Administration, except through the mediation of their own representatives ... [T] he group from the region of Kayes has been the strongest due to the

\footnotetext{
${ }^{57}$ ‘Commission nationale de la jeunesse 1957-1968, PV réunion du jury, semaine régionale de la jeunesse', 29 March 1967, FBPN 52/140, ANM.

${ }^{58}$ Police Spéciale Bamako, 'Renseignements a/s d'une Assemblée générale du syndicat des cheminots tenue le 22.11.62 dans l'enceinte du Chemin de Fer', \#133/C/PS-B, 23 November 1962, FBPN 35/71, ANM.

${ }^{59} \mathrm{Ibid}$.

${ }^{60}$ Police Spéciale Kayes, 'Renseignements: A/s Réunion syndicale des Cheminots', \#99/PSK, 16 November 1961, 1W21, AGRK.

${ }^{61}$ Cercle Kita, monthly report, October 1960, RME 10, MATCL.

${ }^{62}$ Cercle Bafoulabé, monthly report, November 1960, RME 9, MATCL.
} 
poor methods used to find jobs for repatriated agents. ${ }^{63}$ Reports of backroom negotiations at the highest levels of government show that the 'national interests' articulated in economic policy began to diverge from 'the interests of the workers' or at least from those of railway workers. Despite the economic blow to the regional economy and the continued unemployment of hundreds of cheminots who had left Senegal, the leaders of the US-RDA could not agree to negotiating with their western neighbours to reopen the railway to international freight traffic. ${ }^{64}$ In January 1962, police reports complained that merchants in Kayes talked loudly and openly about how the Dakar-Niger railway was Mali's ideal link to ports and world markets, far better than links with Guinea or Côte d'Ivoire.

For the Malians who stayed in Senegal in the wake of the Federation's collapse, the issue of citizenship became particularly charged as its acquisition was required for access to polling stations, social services, and even bursaries for students. Demba Traoré, originally from Kayes, explained how he was obliged to return to Mali following the collapse although he had been a pupil in Diourbel since 1958. ${ }^{65}$ His father had left French Sudan several years earlier for Senegal in order to find work. At the time of his departure from Kayes, he had entrusted his children to his brother. Later, he had managed to bring Demba to Senegal so that he could pursue his education. But because of the collapse, Demba had to acquire Senegalese nationality in order to obtain a bursary and pursue his studies. Yet, his father categorically opposed this. Demba had to return to Mali in January 1961 with his brother, who was in the same situation. Arouna Coulibaly, born in 1940 in Kobongoye in the Senegalese Siin and whose father had migrated from Nioro in French Sudan to Senegal in 1924, was doing the paperwork to establish his citizenship in Senegal when the Federation collapsed. ${ }^{66}$ He ultimately decided to establish his identity papers in the name of Fall, the Wolof equivalent of the Mande patronym Coulibaly, to prevent any further administrative issues because of his Malian origins in this period of high diplomatic tensions.

Independent Senegal struggled with its history as French West Africa's political centre. Nationals of neighbouring countries - particularly Mali - had grounds to make material claims on the Senegalese state without necessarily offering their political support. To avoid a flood of requests, these colonial and federal claims could not be accorded the same status as the needs of Senegalese citizens, and the state limited a broad range of services. This strategy created an environment in which officials judged citizenship applications with an ahistorical view of the country's political past and an eye for minimizing the state's financial obligations. One Sudanese-born applicant who had lived in Senegal since World War One drew a wary note for having a 'definite [financial] interest' in acquiring citizenship in the country that was home to all his material investments as well as the source of his quarterly pension. ${ }^{67}$ The citizenship requirement was stated more explicitly in

\footnotetext{
${ }^{63}$ M. Diarrah, 'Rapport sur la situation de la régie des chemins de fer du Mali', 4 October 1961, p. 3, FBPN 104/404, ANM.

${ }^{64}$ SDECE, 'Difficultés', \#44296/N, 9 May 1961, DIMI 10T 704/1, SHD; SDECE, 'MaliSénégal: au sujet du Dakar-Niger’, \#42711/N, 23 March 1961, DIMI 10T 705, SHD.

${ }^{65}$ Interview by Marie Rodet with Demba Traoré, 29 January 2008, Kayes, Mali.

${ }^{66}$ Interview by Marie Rodet with Arouna Fall/Coulibaly, 9 July 2009, Kobongoye, Senegal.

${ }^{67}$ 'A/s demande de naturalisation [C.G.]', \#359C/SU/RG, 13 June 1962, 2D 13, SRAS-Dakar.
} 
the analysis of the right of a Malian cheminot's widows to collect pensions from the new national railway. ${ }^{68}$ One man born in Kayes had moved to Senegal before his tenth birthday and applied for Senegalese citizenship shortly after leaving the army in late 1961. His file suggests he was a strong candidate: four years of schooling in the colonial system, six years as an apprentice carpenter in the Dakar-Niger workshops in Thiès, and thirteen years of army service, mostly peaceful tours in Senegal. He had never fallen foul of the law and posed no risk to public safety. He spoke fluent Wolof, had married a Senegalese woman, and lodged his family in the home of a Dakar police officer. Although his file indicated that he was 'perfectly integrated into Senegalese society [la collectivité sénégalaise]', he had not held a job since leaving the army six months earlier and had no personal wealth. In his report to the governor of Cap-Vert, the regional police chief opined that such an applicant 'offers nothing of interest to Senegal'. ${ }^{69}$

Around the same time, repatriated cheminots had to navigate between their uncertain position within Mali's shaky economy and the certainty of their memories and enduring relationships in Senegal. Many of the Sudanese cheminots who left Senegal had held important posts in the railway (especially those based in Thiès) and owned property in the city either near the railway's bureaucratic headquarters or in one of the working-class neighbourhoods associated with cheminot life in each station town. In large cities such as Thiès and Tambacounda, their former neighbours managed these properties, collected rents, paid taxes, and at regular intervals transferred the remaining money to the repatriated proprietors in Mali. ${ }^{70}$ Some of these Malian workers returned to Senegal after their retirement, and sometimes even before then, as we shall see, to find their homes waiting for them.

\section{When connected memories strike back}

A Kayes police report from January 1962 noted that:

Those who have not yet been hired back are worried for their future. People believe that they will no longer receive their half-salary. They have no more confidence in the words of the Union and they invade the Government Ministries looking for work. Dissatisfaction reigns in their world and the reaction is that some will not wait to return to Senegal. ${ }^{71}$

Other reactions included that Mali should discourage its citizens from returning to Senegal. '[T]his is serious,' the governor of Kayes wrote in the report's margins. ${ }^{72}$

\footnotetext{
${ }^{68}$ 'A/s demande de naturalisation de [T.A.]', \#506C/SU/RG, 7 September 1962, 2D 13, SRAS-Dakar.

${ }^{69}$ 'Demande de naturalisation [K.A.]', \#503/C/SU/RG, 7 September 1962, 2D 13, SRAS-Dakar.

${ }^{70}$ Interviews by Brandon County with Alhadji Pape Sangane Diop, 23 June 2009, Thiès (Mbambara), Senegal; Abdou Sissokho, 30 June 2009, Tambacounda (Dépôt), Senegal; interviews by Marie Rodet with Cheikh Oumar Tabouret, 16 April 2008, Bamako (Lafiabougou), Mali; Cheick Sidiya Diombana, 5 February 2007, Bamako (Badalabougou), Mali.

${ }^{71}$ Police Spéciale Kayes, Report, January 1962, 1W21, AGRK.

${ }^{72}$ Ibid.
} 
So serious, in fact, that some had already tried it. One cheminot returned to Senegal in February 1962 and submitted his application for Senegalese citizenship shortly thereafter, despite his expulsion from the country less than a year and a half before. '[I] only need to be naturalized to return to my work on the D.N. in Senegal,' he explained, treating his application as if it were a bureaucratic formality and alluding to a waiting job on the Dakar-Niger railway, which no longer existed. 'I did not have a job in Mali,' he added as a postscript. ${ }^{73}$ Officials in Dakar picked up on this, deciding that 'his choice is only guided by the need to recover the job that he had left after 20 August'. ${ }^{74}$

The threat of migration - by cheminots and others - made trains and railway stations important sites for the expression of state power (Rodet and County forthcoming). In 1961, the Senegalese government deemed rumours of Malian plans to demolish the railway tracks between Kayes and the border part of a hard-line policy meant to encourage Malians residing in Senegal to repatriate and isolate those who did not. ${ }^{75}$ Indeed, when Senegal began a short-lived policy of requiring Malian travellers to have visas in late 1961, the US-RDA branch in Kayes suggested that the government suspend all train services with Senegal and transfer the railway's western terminus to Gouloumbo, 20 miles east of the border. ${ }^{76}$

Despite the closure of the border until 1963, intermittent trade between the two countries continued via the road from Kayes (Lambert 1993: 43). Neither government could reconfigure the region's long-standing migratory networks, as stated by Malian administrative reports that regularly denounced the circumvention of the border via Mauritania by Malian nationals attempting to reach Senegal. ${ }^{77}$ State officials often cited train stations on the border and far beyond it as sites of anti-national activities such as emigration and smuggling. Memories of Senegal's break with the Federation lived on, underscoring the border's political threat and the problematic nature of train travel. '[I]n each train from "Katanga", ${ }^{78}$ local officials in Kayes complained in 1962, "comrades come and go without luggage. These people deserve to be watched. ${ }^{79}$ Those most suspect were the ones coming from Senegal, 'foreigners' who brought dubious morals, economically unproductive enterprises, and political subversion. ${ }^{80}$ To stop the flow of illegal importations from Senegal, the governor of

\footnotetext{
${ }^{73}$ Sûreté Région Cap-Vert, 'Renseignements Généraux', \#156/SU/RG, 13 September 1962, 2D 13, SRAS-Dakar.

${ }^{74}$ 'Chef Services Police Région Cap-Vert to GRC-V', \#548C/SU/RG, 26 September 1962, 2D 13, SRAS-Dakar.

75،Activités des maliens', 3 January 1960 [sic; 1961], 5D 15, SRAS-Dakar.

76، BPL Kayes to Sec Gen US-RDA', 8 September 1961, FBPN 239/857, ANM.

77، MIIT to GRK', \#285/MIITCAB, 6 September 1961, 1W5, AGRK.

${ }^{78}$ People in Kayes and in train stations across Mali named the Falémé River bridge 'Katanga', a reference to the condemned secessionist province in Congo-Léopoldville. Interview by Brandon County with Dramane Touré, 29 August 2004, Kayes (Plateau), Mali. Further east, in Kita, '[e]vents in the ex-Belgian Congo were frequently discussed, especially by the teachers and students on vacation from school'. Kita Cercle, monthly report, August 1960, p. 5, RME 10, MATCL. Immediately after the 19-20 August crisis, Senegalese security forces reported Sudanese residents of Thiès saying that 'Senegal's position is the same as that of Katanga in the former Belgian Congo'. 'Compte rendu de renseignements fournis par le groupe de Thiès sur la situation politique', \#3/S, 21 August 1960, 5D14, SRAS-Dakar.

${ }^{79}$ Cercle Kayes, 'PV chefs services', 31 January 1962, 1W15, AGRK.

${ }^{80}$ 'Min Intérieur Information Tourisme to GRegions', \#40/DI, 25 July 1962, 1W14, AGRK.
} 
Kayes made provisions for four members of the party's youth wing to ride the trains along 175 miles of track between Mahina and the border to prevent the movement of both smuggled goods and smugglers. ${ }^{81}$ Even with heightened surveillance, officials throughout western Mali continued to see 'Malians flock to the station in order to continue to Senegal or France'. ${ }^{82}$

In Kayes, the economic decline caused by the closed border with Senegal, its position at the far west of the country, and political disagreements with the central government and neighbouring administrative districts that stemmed from this distanced the city from the rest of the country. Tidiani Traoré, a politician from Kayes, came under scrutiny from the US-RDA's radical wing in January 1961 after having decried the 'suffocation' faced by Kayes with the rail line closed. ${ }^{83}$ Traoré was denounced as a Senegalese agent, but the following month a joint meeting of government ministers swept the most serious charges aside, explaining: 'We can only reproach Tidiani for having spoken about reestablishing the railway between Mali and Senegal, even though the anger born from the collapse of the Federation has not yet dissipated in us.' While admitting that support for re-establishing the railway did not necessarily mean collusion with Senegal, the Malian politicians were effectively acknowledging that the August 1960 plan to halt transborder railway services stung Mali more than Senegal. ${ }^{84}$

Throughout the closed-border period, the railway question coloured all political discussion in Kayes. Senegalese intelligence reports from the summer of 1961 indicate that enormous pressure was being put on Modibo Keita to do something about re-establishing a rail link. Geographically and politically, people in Kayes felt isolated from the rest of the country. The city's financial affairs suffered so greatly that two wealthy merchants from the region proposed a plan in which Mali could solve its problems with the politically troublesome and administratively remote districts of Nioro and Kayes by transferring them to neighbouring Mauritania and Senegal. ${ }^{85}$ National leaders worried that the growing number of public expressions of popular discontent in the region were tied to the government's inability to find employment for nearly half of the repatriated cheminots who had left Senegal, while further insisting that 'the regionalist attitude in Kayes must be denounced and combated'. ${ }^{86}$ And, in Bafoulabé, Koli Sissoko scandalized 100 National Assembly deputies by saying that the district of Bafoulabé would be better off in Senegal. ${ }^{87}$ Residents of Mali's westernmost cities grudgingly acknowledged the Senegalese assessment that Kayes was 'a state within the state' in Mali. ${ }^{88}$

As the US-RDA tightened its control over Malian politics, overt challenges to authority were tolerated less and less. The number of secret police reports from this

\footnotetext{
${ }^{81}$ 'Cdt Kayes to GRK', \#299/AE, 6 February 1962, 1W15, AGRK.

${ }^{82}$ Cercle Kayes, 'Compte rendu de la conférence des chefs de service', November 1962, 1W4, AGRK.

${ }^{83}$ SDECE, 'Au sujet de M. Tidjani Traoré', \#40442/N, 30 January 1961, DIMI 10T 704/1, SHD.

${ }^{84}$ 'République du Mali', 28 February 1961, 5D 15, SRAS-Dakar.

${ }^{85}$ 'A/s République du Mali', 8 June 1961, 5D 15, SRAS-Dakar.

${ }^{86}$ US-RDA BPN, PV, 21 March 1962, FO 77, ANM.

${ }^{87}$ Cercle Bafoulabé, Report, December 1964, p. 8, 1W67, AGRK.

${ }^{88}$ "Sidibé Ibrahim to "Mon Cher Sory", early 1962, FBPN 239/857, ANM.
} 
period testifies to the extent of the surveillance that Kayesian politics merited according to the central government. When the contents of one report were leaked to cheminots in the summer of 1962, police feared that the resulting public outcry over the practice would drive subversive political discussion further underground. ${ }^{89}$

Even after reconciliation with Senegal in $1963,{ }^{90}$ authorities in Mali viewed railway travel with suspicion. While officials in Kayes said that relations between officials and civil servants in the Cercle were generally good, the head of the Ambidédi district believed that the town's stationmaster should be kept under close watch. ${ }^{91}$ The local party branch complained that the customs service's request to halt all international passenger services at Ambidédi both undermined the city's functional role as an administrative centre and imposed an unnecessary burden on travel and communication between the westernmost towns along the railway and the rest of the country. ${ }^{92}$ In a 1964 union meeting, one cheminot complained:

The city of Toukoto ... is, for me and for many of my comrades, our primary residence. Four local customs agents in the train station spare no traveller in what they call the execution of their duty. They dig through all the luggage, registered or not, at arrival as well as at departure, no matter the destination or origin, be it within or beyond the borders of this country ... Thiémoko's widow ... coming from Bamako and still in mourning, was [a] victim of this abuse, much to the dismay of the people gathered around..$^{93}$

In 1965, a police officer reported that an old woman living in Kayes had been reported at the Diboli station before reaching Kidira. ${ }^{94}$ She had woven amulets into her hair and had hidden within them the total sum of 30,010 Malian francs and 1,650 CFA francs. She had obtained a circulation permit from her son-in-law in order to travel from Kidira to Dakar.

By 1967, trains and stations served as sites for a growing number of internecine conflicts between state institutions and branches of the US-RDA, particularly the party militia that assumed an even more important role after the national government inaugurated its socialist 'Active Revolution' in 1967. Just as customs agents had upset cheminots in 1964, militia bands upset customs agents as well as railway passengers by searching all trains from Bamako to the border and beyond, and relieving passengers of anything that they considered to be questionable. The railway administration did not like this because it upset their clients. And the general population worried that the militia was taking over the operations of certain state institutions such as the railway. ${ }^{95}$

\footnotetext{
${ }^{89}$ 'Commissaire Police Kayes to GRK', \#109/C, 17 July 1962, 1W14, AGRK.

${ }^{90}$ Under the influence of the newly formed Organization of African Unity, Senghor and Modibo Keita met at the Senegal-Mali border in Kidira on 22 June 1963 to reopen the railway and to sign a cooperation pact between the two states.

${ }^{91}$ Cercle Kayes, monthly report, January-February 1964, RME 30, MATCL.

92،Sous-Section Ambidédi to Sec Gen US-RDA c/o Sec Gen BPL Kayes', 9 November 1964, FBPN 239/857, ANM.

${ }^{93}$ 'CFM Groupe Politique du MR, PV Assemblée General', \#28, 10 October 1964, p. 2, FBPN 224/736, ANM.

94'Compte rendu de gendarmerie, G.I.G Kayes', 9 February 1965, 1W110, AGRK.

${ }^{95}$ 'Action de la Milice au sein de certain services d'état', 15 December 1967, FBPN 146/568, ANM.
} 
In March 1967, local US-RDA sections along the railway received a circular from Idrissa Diarra, the US-RDA national political secretary, warning them of a threat posed by a group of anonymous cheminots spreading political tracts and rumours that criticized the UNTM (Union nationale des travailleurs du Mali $^{96}$ and the US-RDA and questioned the motives of politically active workers who defended either group. Such paranoia was not limited to the railway, but the railway presented a special problem because it 'brought into the open the real position of certain anti-party elements, camouflaged in the cheminots' ranks, who plan to create a climate of social disorder'. The subversive threat came from the cheminots' ability to relocate themselves all over the line, organize meetings and take advantage of their networks. Faced with such an egregious 'violation of our party's principles of sacrifice and patriotism', Diarra ordered local branches to keep watch on all travel and political activity in station towns. ${ }^{97}$ Later that year, public speeches by union leaders at Mali's national cheminot conference all stressed the line's economic importance to the country and the related obligation that cheminots needed to address 'the need to reinforce unity within the union and ideological training for the workers on the rails in order to prevent the return of certain hidden anti-revolutionary activities which had cast doubt on the cheminots' revolutionary credentials and gravely compromised the railway's economic worth' ${ }^{98}$ While the central government clearly saw in some cheminots' actions a growing political threat and anti-national behaviour, one can wonder to what extent these were not just some of the few circumventing strategies adopted by long-standing diasporic communities along the railway in order to fight against top-down ascribed national identity and behaviours in an increasingly repressive political climate.

\section{Conclusion: a claim to translocal belonging along the railway}

Announcing the constitutive congress of the Republic of Mali's national union of railway workers on 26 September 1960, Mali's state radio lamented the unilateral treason of Senegalese leaders Dia and Senghor, whose desire to leave the Federation had torn apart a 'railway brotherhood woven together over so many decades' ${ }^{99}$ But the broadcast had more resonance in the world of politics than in the railway centres of the two new states. Indeed, the Senegalese maxim Kees-Kaay: benn dëkk, ñaari gaar (Wolof: 'Thiès and Kayes: one city with two train stations') held true: the ties between the countries proved stronger than the animosity between the states. Even the history of 19-20 August 1960 published by Senghor and Dia's government acknowledged the two countries' strong ties. The authors emphasized Sudanese responsibility for the Federation's collapse, while at the same time they insisted that the difference between the two countries

\footnotetext{
${ }^{96}$ The UNTM was created in 1963 and is the main trade union in Mali.

97'US-RDA BPN to BPL Bafoulabé, Kayes, Kita, and Koulikoro', \#12-Letter-Circulaire, 11 March 1967, dossier 'Affaires politiques du Cercle de Kayes et du Parti \#7', Archives du cercle de Kayes.

98،IRT 1ère Région to Min Travail', \#57/IRT/K, 12 May 1967, carton 19, AGRK.

${ }^{99}$ Broadcast introduction, 26 September 1960, BK 26, ORTM Archives sonores.
} 
was primarily political, counselling readers that Senegal would 'wait for tempers to calm' before talking to Keita's government: 'We refuse to cause irreparable damage to the Sudanese' (République du Sénégal 1960: 30). If politicians in Bamako abandoned their dreams of restoring the Federation or punishing Senegal for leaving it, the Senegalese officials advised, then in Mali and in Senegal "children and grandchildren can again take up our ties of friendship and brotherhood that exist between these two peoples so closely related [deux peuples frères]'. ${ }^{100}$

Such ties were closest along the railway, including among people who, while not railway employees themselves, benefited economically and socially from the railway. Sitting in his home's courtyard across the tracks from the Mahina train station, Mamadou Diakite recalled his 'return' to the Republic of Mali as a move that was both unproblematic and fraught with danger. Born in Senegal to a cheminot from Mahina and the daughter of migrant farmers who left the Niger River valley to settle in Senegal's peanut basin, Diakité spent most of his first thirty years in Senegal but relocated to Mali in 1962 at the request of his repatriated father. Except for his midnight border crossing - when Senegalese guards alternately coaxed him back to the riverbank and shot at his truck - the voyage was uneventful. Arriving in Kayes, Diakités father arranged for cheminot friends to ship him and the truck to the family home in Mahina. Over the next year, Diakité and his three brothers travelled between Mali, Burkina Faso and Côte d'Ivoire, driving the truck as a small-scale business, working in a series of odd jobs, and enduring the material and moral challenges that come with life away from home. 'Tunya man lambe lon,' he said, repeating the Xaasonga adage that exile knows no dignity. Bandits preyed on travellers along Burkina Faso's roads and tales of sorcery and cannibalism terrified migrant farmhands in Côte d'Ivoire, but in Diakité's story, people in Mali and Senegal lived safe from these threats. This sense of tranquillity infused his whole narrative. As of 2009, all four brothers had settled between Mahina and Toukoto, and none of them strayed far from the line. The railway, Diakité explained, was their dignity: 'Anw ka danbe de dòn [It is our dignity].' ${ }^{101}$ Having faced the privations of life abroad, the four Diakité brothers had chosen to guard their honour by staying close to the railway.

Relocation along the tracks over generations engendered change within a socially and culturally acceptable continuum. Sissokos and Sakilibas (common Mande patronyms) moving from Sudan settled in Wolofophone western Senegal as Guèyes (Guèye is the Wolof equivalent of Sissoko and Sakiliba); Falls and Coulibalys could alternate their family names based on local linguistic practices, political considerations and personal inclinations. ${ }^{102}$ In the colonial period, migrants from French Sudan and the upper Senegal River valley entered the administrative record having changed their Mande and Fulbe names to local Wolof forms

\footnotetext{
${ }^{100}$ 'Entretien avec les autorités Sénégalaises à TAMBA le 28-2-61', 28 February 1961, FBPN 88/300, ANM.

${ }^{101}$ Interview by Brandon County with Mamadou Diakité, 20 January 2009, Mahina (Mahina 3e), Mali.

${ }^{102}$ Interview by Marie Rodet with Arouna Fall/Coulibaly, 9 July 2009, Kobongoye, Senegal; interviews by Brandon County with Maciré Coulibaly, 22 July 2007, Thiès (Diamaguène), Senegal; Arouna Fall, 26 December 2008, Markala (Diamarabougou), Mali; Amadou 'Nsònsòn' Guèye, 5 July 2009, Guinguinéo (Kanène), Senegal.
} 
(Pheffer 1975: 312). Some changed them back again during the Sudanese ascendency in Mali Federation politics (Foltz 1965: 149). And some changed only after being expelled from Senegal. Other migrants stubbornly refused to change. 'Beninese Keitas, Ivorian or Guinean Diops, Malian Guèyes' across the territory of the former French West Africa, and particularly across its now international borders, shaped diasporic communities, in some cases continuing to call Mali their 'homeland' despite never having visited the country of their ancestors (Keita 1983: 54).

Anthropologist Bruce Whitehouse describes the Mande idea of 'dignity' (Bamana: danbe; Xaasonga: lambe) as a 'place-bound attribute, inextricably linked with local social hierarchies and family histories' (Whitehouse 2012: 21). Dignity is lost in exile because travellers move alone - or sometimes in groups away from the people who give shape to the hierarchies and away from societies where their histories have meaning. Another Mande proverb emphasizes the productive role of place in the concept of dignity. Woloyòrò mòyòrò bè danbe dafa - a place to be born and grow old brings dignity. Dignity is produced in space, and a dignified life can be lived only in this space (Bailleul 2005: 324). For cheminots railway workers as well as family members such as Diakite - 'the railway' is a space produced by railway-specific conceptions of genealogy and administration, the perceptions of socially important work, and the rhythms of lived experience that were only possible with the comings and goings of the trains. With the collapse of the Mali Federation in 1960, these conceived, perceived and life spaces all clashed with hardening national cartographies. As Diakité suggested, exile knows no dignity, but some of these communities found their dignity in the railway as the backbone of their diasporic identity. Moving from Mali to Senegal was not an 'exile', nor was the reverse necessarily a 'return'. As long as the trains circulated, the international border only marked the difference between two states; it could not fundamentally disrupt the long-standing cultural continuum along the railway.

\section{References}

Bailleul, C. (2005) Sagesse bambara: proverbes et sentences. Bamako: Éditions Donniya.

Bazin, J. (1985) 'A chacun son Bambara' in J.-L. Amselle and E. Mbokolo (eds), Au cour de l'ethnie. Paris: La Découverte.

Campmas, P. (1978) 'L'Union Soudanaise (section du RDA) 1946-1968'. PhD thesis, Université de Toulouse Le Mirail.

Cissoko, S. M. (2005) Un combat pour l'unité de l'Afrique de l'ouest: la Fédération du Mali (1959-1960). Dakar: Nouvelles Éditions Africaines du Sénégal.

Cooper, F. (1996) Decolonization and African Society: the labor question in French and British Africa. Cambridge: Cambridge University Press.

Cooper, F. (2015) Français et Africain? Être citoyen au temps de la décolonisation. Paris: Payot.

County, B. and R. Skinner (2008) 'Faso and Jamana: provisional notes on Mande social thought in Malian political discourse, 1946-1979' in S. Belcher, J. Jansen and M. N'Daou (eds), Mande Mansa: essays in honor of David Conrad. Münster: LIT Verlag. 
David, P. (1980) Les navetanes: histoire des migrants saisonniers de l'arachide en Sénégambie des origines à nos jours. Dakar: Nouvelles Éditions Africaines.

Diarrah, C. O. (1986) Le Mali de Modibo Keita. Paris: L'Harmattan.

Foltz, W. J. (1965) From French West Africa to the Mali Federation. New Haven CT: Yale University Press.

Gary-Tounkara, D. (2008) Migrants soudanais/maliens et conscience ivoirienne: les étrangers en Côte d'Ivoire (1903-1980). Paris: L'Harmattan.

Grillo, R. D. (1973) African Railwaymen: solidarity and opposition in an East African labour force. Cambridge: Cambridge University Press.

Joly, V. (2014) 'Du Soudan français à la République du Mali. Une indépendance dans la douleur (1956-1961)' in P. Oulmont and M. Vaïsse (eds), De Gaulle et la décolonisation de l'Afrique subsaharienne. Paris: Karthala.

Jones, J. A. (2002) Industrial Labor in the Colonial World: the workers of the chemin de fer Dakar-Niger, 1881-1963. Portsmouth NH: Heinemann.

Keita, J. (1983) Connais-tu mon beau pays? Bamako: n.p.

Kurtz, D. N. (1970) 'Political integration in Africa: the Mali Federation', Journal of Modern African Studies 8 (3): 405-24.

Lambert, A. (1993) 'Les commerçantes maliennes du chemin de fer DakarBamako' in E. Grégoire and P. Labazée (eds), Grands commerçants d'Afrique de l'Ouest. Logiques et pratiques d'un groupe d'hommes d'affaires contemporains. Paris: Karthala-ORSTOM.

Malkki, L. (1992) 'National geographic: the rooting of peoples and the territorialization of identity among scholars and refugees', Cultural Anthropology 7 (1): 24-44.

Manchuelle, F. (1997) Willing Migrants: Soninke labor diasporas, 1848-1960. Athens OH: Ohio University Press.

Mann, G. (2015) From Empires to NGOs in the West African Sahel: the road to nongovernmentality. New York NY: Cambridge University Press.

Meillassoux, C. (1968) Urbanization of an African Community: voluntary associations in Bamako. Seattle WA: University of Washington Press.

Ndiaye, G. (1980) L'échec de la Fédération du Mali. Dakar: Nouvelles Éditions Africaines du Sénégal.

Ngũgĩ wa Thiong'o (2009) Something Torn and New: an African renaissance. New York NY: Basic Civitas.

Pheffer, P. E. (1975) 'Railroads and aspects of social change in Senegal, 18781933'. PhD thesis, University of Pennsylvania.

République du Sénégal (1960) Livre blanc sur le coup d'état manqué du 19 au 20 août 1960 et la proclamation de l'indépendance du Sénégal. Dakar: Ministère de l'Information de la Presse et de la Radiodiffusion.

Rillon, O. (2013) 'Féminités et masculinités à l'épreuve de la contestation. Le genre des luttes sociales et politiques au Mali (1954-1993)'. PhD thesis, Université Paris 1 - Panthéon Sorbonne.

Rodet, M. (2008) 'Genre, migration et réseaux familiaux au Haut-Sénégal, 1907-1950', Revue Diasporas: Etrangères 11: 25-36.

Rodet, M. (2009) Les migrantes ignorées du Haut-Sénégal (1900-1946). Paris: Karthala.

Rodet, M. (2015) 'Escaping slavery and building diasporic communities in French Soudan and Senegal, c.1880-1940', International Journal of African Historical Studies 48 (2): 1-24. 
Rodet, M. and B. County (forthcoming) 'Genre, génération et contrôle de la circulation des personnes entre le Mali et le Sénégal à l'heure de Modibo Keita (1959-1968)' in M. Gomez (ed.), Femmes d'Afrique et émancipation. Entre normes sociales contraignantes et nouveaux possibles. Paris: Karthala.

Rodet, M. and C. Reinprecht (2013) 'Mémoires et migrations en Afrique de l'Ouest et en France', Revue Européenne des Migrations Internationales 29 (1): 7-22.

Samaké, D. (1998) 'Les refoulés du Sénégal après l'éclatement de la Fédération du Mali en 1960'. Mémoire de fin d'études (degree thesis), Histoire-Géographie, Université du Mali, École Normale Supérieur.

Tixier, G. (1965) 'La succession à la Régie des chemins de fer de l'AOF: problèmes posés par l'apparition des nouveaux États', Annuaire Français de Droit International 11: 916-32.

Traoré, A. S. (2005) Devoir de mémoire, devoir de vérité. Bamako: La Ruche à Livres.

Whitehouse, B. (2012) Migrants and Strangers in an African City: exile, dignity, belonging. Bloomington IN: Indiana University Press.

Zuccarelli, F. (1988) La vie politique sénégalaise (1940-1988). Paris: Centre des Hautes Études sur l'Afrique.

\begin{abstract}
This article examines concepts of 'home' and 'abroad' for migrants and citizens in the twilight of empire. It focuses on the 'cheminots refoulés', railway workers with origins in the former French Sudan (today's Republic of Mali) who were expelled from Senegal shortly after both territories declared independence, and other 'Sudanese' settled in Senegal, sometimes for several generations. Using newly available archives in France, Mali and Senegal, and interviews with former cheminots and 'Sudanese migrants' on both sides of the border, this article seeks to historicize memories of autochthony and allochthony that have been constructed and contested in postcolonial nation-building projects. The Mali Federation carried the lingering memory of federalist political projects, but it proved untenable only months after the Federation's June 1960 independence from France. When member states declared independence from each other, the internal boundary between Senegal and the Sudanese Republic became an international border between Senegal and the Republic of Mali. In the wake of the collapse, politicians in Bamako and Dakar clamoured to redefine the 'nation' and its 'nationals' through selective remembering. Thousands of cheminots and 'Sudanese migrants' who had moved to Senegal from Sudan years (or decades) earlier were suddenly labelled 'foreigners' and 'expatriates' and faced two governments eager to see them 'return' to a hastily proclaimed nation state. This 'repatriation' allowed Republic of Mali officials to 'perform the nation' by (re)integrating and (re)membering the migrants in a nascent 'homeland'. But, having circulated between Senegal and Sudan/Mali for decades, 'Sudanese migrants' in both states retained and invoked memories of older political communities, upsetting new national priorities. The loss of the Mali Federation raises questions about local, national and international citizenship and movement in mid-century West Africa. Examining the histories invoked to imagine postcolonial political communities, this article offers an insight into the role that memory has played in constructing and contesting the nation's central place in migration histories within Africa and beyond.
\end{abstract}




\section{Résumé}

Cet article examine les concepts "d'être chez soi » et "d'étranger » pour les migrants et les citoyens au crépuscule de l'empire. Il porte son attention sur les " cheminots refoulés » originaires de l'ancien Soudan français (l'actuelle République du Mali) qui furent expulsés du Sénégal peu après la déclaration d'indépendance de ces deux pays. Il s'intéresse également aux autres « Soudanais » installés au Sénégal, parfois sur plusieurs générations. À partir d'archives récemment ouvertes en France, au Mali et au Sénégal, et d'entretiens avec d'anciens cheminots et « migrants soudanais ", de part et d'autre de la frontière, cet article cherche à historiciser les mémoires d'autochtonie et d'allochtonie construites et contestées dans des projets postcoloniaux de construction nationale. La Fédération du Mali se voulait porteuse de la mémoire persistante de projets politiques fédéralistes, mais elle s'avéra indéfendable quelques mois seulement après l'indépendance de la Fédération de la France en juin 1960. Avec la rupture de la Fédération, la frontière intérieure entre le Sénégal et la République soudanaise devint une frontière internationale entre le Sénégal et la République du Mali. À la suite de cet effondrement, les politiciens à Bamako et à Dakar appelèrent à redéfinir la " nation » et ses " nationaux » par un processus de souvenir sélectif. Des milliers de cheminots et de " migrants soudanais » qui avaient quitté le Soudan pour se rendre au Sénégal des années (voire des décennies) auparavant furent soudain étiquetés "étrangers 》 et " expatriés ", confrontés à deux gouvernements désireux de les voir " retourner " dans un État-nation proclamé à la hâte. Ce « rapatriement » permit aux responsables de la République du Mali de « performer la nation » en (ré)intégrant les migrants et en les obligeant à (ré)adhérer à une " patrie » embryonnaire. Or, ayant circulé entre le Sénégal et le Soudan/Mali pendant des décennies, ces «migrants soudanais " conservaient des souvenirs de communautés politiques bien plus anciennes, qu'ils commencèrent dès lors à revendiquer, contrariant ainsi les nouvelles priorités nationales. La fin de la Fédération du Mali interroge les citoyennetés locales, nationales et internationales et la mobilité en Afrique de l'Ouest dans la deuxième moitié du vingtième siècle. En examinant les récits invoqués pour imaginer des communautés politiques postcoloniales, cet article apporte un éclairage nouveau sur le rôle qu'a joué la mémoire dans la construction et la contestation de la centralité de la nation dans les récits migratoires en Afrique et ailleurs. 